\title{
The Implications of the Cultural Values of Individualism and Collectivism in the Formation of the Psychological Contract and Employee Commitment
}

\author{
Jeffrey N. Street \\ Idaho State University
}

\begin{abstract}
We examine here employee commitment to the organization as an outcome variable of the psychological contract, generally defined as the employee's perception of what will be received from the employer in exchange for work. As a context for the formation of the psychological contract, cultural values of individualism and collectivism are considered as antecedents in a proposed research model. The study is conceptual in nature, however, propositions related to the effect of individualism and collectivism on the type of psychological contract formed, transactional or relational, and the subsequent component of commitment realized, affective, continuance, or normative, are offered.
\end{abstract}

\section{Introduction}

In the field of strategic management emphasis is placed on the effective and productive use of an organization's resources to gain a sustainable competitive advantage (Barney, 1991; Chase, et al., 2001; Hitt, et al., 2007; Dess, et al., 2008). Contemporary to today's environment, the focus of the sustainable competitive advantage is on the global marketplace as firms have increased their operations around the world.

Significant interest exists in identifying and studying the competitive advantage of the Japanese manufacturing base over that of the United States. The focus of research has been predominantly centered on technology, management methods, and business policy. However, this study suggests that an aspect of human capital, commitment of the workforce to the organization, may be a key factor.

Assets that represent the wealth of a company are money, land, equipment and human capital (Leana \& Rousseau, 2000). Of these assets, the human capital of a company is more unique than any other resource in that it cannot be easily replicated by a competitor. The uniqueness of human capital comes from the culture of the country where the firm operates, the demographic make-up of the workforce, and the human resource practices of the company. By tapping into the expertise and creativity of the workforce, better and more broadly acceptable solutions to an organization's problems are likely to result (Rohleder \& Silver, 1997). Hence, the effective and productive use of the workforce, or manpower as it is commonly called, is important in establishing a sustainable competitive advantage through the development of competencies that are firm specific (Lado \& Wilson, 1994; Hitt, et al., 2007; Dess, et al., 2008).

Therefore, if manpower is classified as human capital of a company (Hayes, 1981) then it may also be classified as an asset. Then, how does the firm take ownership of the asset of manpower or people? Machines and materials can be purchased, becoming 
tangible assets owned by the company. However, people, or employees, cannot be owned by the organization. What binds an employee to his or her company is commitment. Herskovitch and Meyer (2002) define commitment as a force or mind-set that binds an individual to a course of action, subsequently increasing the likelihood the employee will remain with the organization. Commitment that originates within the psyche of the employee based on the perception of what he or she will gain from the organization and whether the relationship will be good for the employee. Commitment that is sustained by the actions of the members of the organization during the time the employee is with the company. Commitment fostered by the idiosyncrasies of the culture and society in which the firm conducts business. Thus commitment enables the employer to have quasi-ownership of the employee.

The research model of this study focuses on commitment as an outcome variable of the employee's perception of what will be received from the employer in exchange for work. The theory explored is the psychological contract (Rousseau, 1989, 1990, 1995, 2001). The contribution to the existing literature on commitment and the psychological contract is the addition of the cultural values of individualism and collectivism (Hofstede, 1980) as the context for the formation of the psychological contract. The individualism versus collectivism context is added to expand the view of the psychological contract in relation to its effect on the operations of multi-national firms.

\section{Theoretical Background}

The psychological contract is beliefs of an individual, shaped by an organization, regarding the terms of an exchange agreement between the individual and the organization (Rousseau, 1989, 1990, 1995; Rousseau \& Wade-Benzoni, 1994). Further defined, psychological contracts in the employment context are the belief systems of individual workers and employers regarding their mutual obligations (Rousseau, 1989, 1995; Morishima, 1996; Rousseau \& Schalk, 2000). Specifically, such contributions as work, effort, and cooperation that the employee owes the employer and the inducements and rewards that the employee believes are owed in return (Morishima, 1996). For example, the employee might believe that the organization has made certain implied promises, such as long-term job security and future promotion opportunities, in exchange for the employee's work effort and loyalty to the organization (Rousseau, 1989, 1990; Shore \& Tetrick, 1994). The perception of promises between the employer and the employee is a key to the establishment of the psychological contract.

The employee can perceive the promises of the psychological contract by such mechanisms as recruiting information, interviews, orientation programs, and organizational practices of the employer (Rousseau \& Wade-Benzoni, 1994; Thomas \& $\mathrm{Au}, 2000)$. It is difficult for employers to specify all of the terms and conditions of the employment relationship, individuals must supplement the information when forming their psychological contract (Arai, 1998; Thomas \& Au, 2000). Fostering the creation of the psychological contract by the employer involves messages (Rousseau, 1989), signals, and social cues from the members of the organization in the form of explicit statements of rewards for contributions, expressions of organizational policy, and 
references to history or reputation. In response, the psychological contract of the employee is formed by the individual's interpretation (Rousseau \& Wade-Benzoni, 1994), predisposition (Rousseau, 1995), and the mental model created from the meaning of the related elements (Rousseau, 2001) presented by the organization.

Much of that which the employee expects from employment is derived from societal stipulations regarding employment and not from the employee's relationship with a particular employer (Rousseau \& Schalk, 2000). Beliefs inherent in the psychological contract continue their formation as the employee affiliates with a group or groups in the employer's organization having similar attributes, such as membership in the same department or business unit, hierarchal position, demographics, or perhaps ethnicity or nationality (Rousseau \& Schalk, 2000). Because of the perceptual nature of the psychological contract there is a possibility that cultural differences influence the makeup of the agreement (Thomas \& Au, 2000). Cultural values of individualism and collectivism (Hofstede, 1980) may be particularly important in respect to the psychological contract since the contract involves the perception of the individual in relation to the larger organization.

Fundamentally, individualism and collectivism can be described as the way a person builds the concept of himself or herself in relation to a social group (Thomas \& Au, 2000). Here we consider the social group to be an organization (i.e., firm). Collectivism refers to the tendency of an individual to define himself or herself in part by his or her relationships with others (Markus \& Kitayama, 1991; Triandis, 1995) or perhaps to an ingroup that others belong to (Triandis, 1995; Thomas \& Au, 2000). Individualism is when the individual defines himself or herself as independent of others with principles such as freedom of choice, self-determination (Thomas \& Au, 2000) and autonomy dominating his or her behavior. Broad standard beliefs and values such as collectivism and individualism are built into the composition of different cultures (Segall et al., 1999; Thomas \& Au, 2000) and influence the attitudes of individuals with regard to their relationship with their organization. A characteristic of culture is that it is not innate, but learned through the sharing and effects of different groups (Hall, 1976). When an individual is socialized into a particular cultural group he or she learns how to perceive (Thomas \& Au, 2000). An individual's perception defines the terms of the psychological contract.

From a cross-cultural or cross-national perspective, interpretation of promises is shaped by the setting and society in which the employment takes place; the psychological contract is reinforced by the society's standards (Rousseau \& Schalk, 2000). See Figure 1. For the employee and the employer to commit to the psychological contract, the requirements of the society are (i) personal freedom of choice for the employee and employer, and (ii) social stability of the organization and environment. The role of society in shaping the psychological contract depends on how much of the terms and conditions of the work are negotiable and how much is specified by the firms of the society (Rousseau \& Schalk, 2000). Organizational practices of a foreign-based firm (such as a Japanese company operating in the U.S.) that are more characteristic of the 
firm's home country culture (Aoki, 1994) can alter the effect of local society on the individual's perception of the psychological contract.

Effective psychological contracting is critical to creating competitive opportunities for workers and firms in the global economy (Rousseau \& Schalk, 2000). Those firms whose human resource practices improve the training, capability and quality of the workforce above levels typically available in a particular society should realize a comparative advantage in performance (Chase et al., 2001).

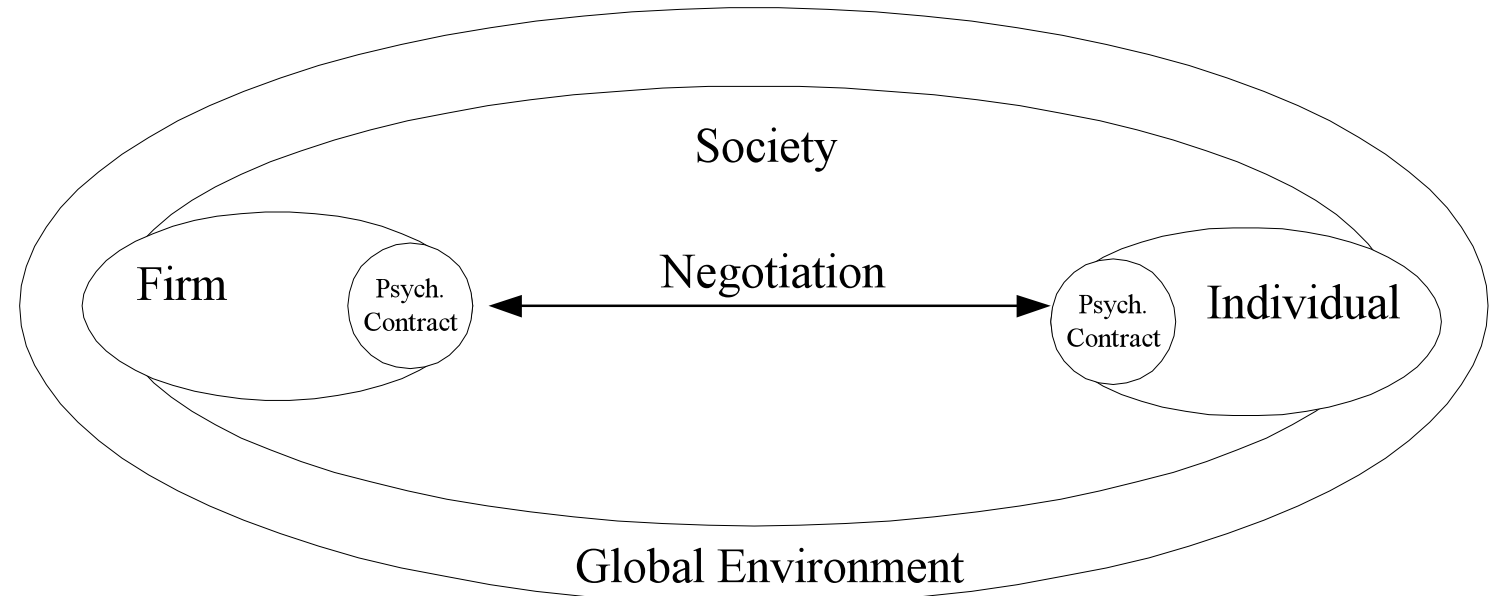

Figure 1. "Key Contexts for Psychological Contracting" (Rousseau and Schalk, 2000, pg. 2)

The psychological contract is a perception and is manifested as an unwritten agreement and thus, is not concrete (Gakovic \& Tetrick, 2003). Commitment of the employee to the organization is tied to the concept of the psychological contract (Rousseau, 1989).

Commitment is an important outcome of the psychological contract. Commitment can cause the employee to remain with the organization and lack of commitment can cause the employee to leave the organization. Commitment might be the foundation upon which employers and employees cooperate concerning organizational changes and new human resource practices that are undertaken by the organization in an attempt to achieve a sustainable competitive advantage.

\section{Research Model}

In a review of the work of Meyer and colleagues on organizational commitment, three forms of commitment have been identified (Meyer \& Allen, 1991). Affective commitment, which is an affective attachment to the organization, is typified by the employee who wants or desires to remain with the company. Continuance commitment, which is commitment as a perceived cost associated with leaving the company, typified by the employee who needs to stay with the company. Normative commitment, which is commitment as an obligation to remain with the company, typified by the employee who feels he ought to stay with the company (Meyer et al. 1993). These three forms of commitment are identified as outcome variables for the research model. See Figure 2. 


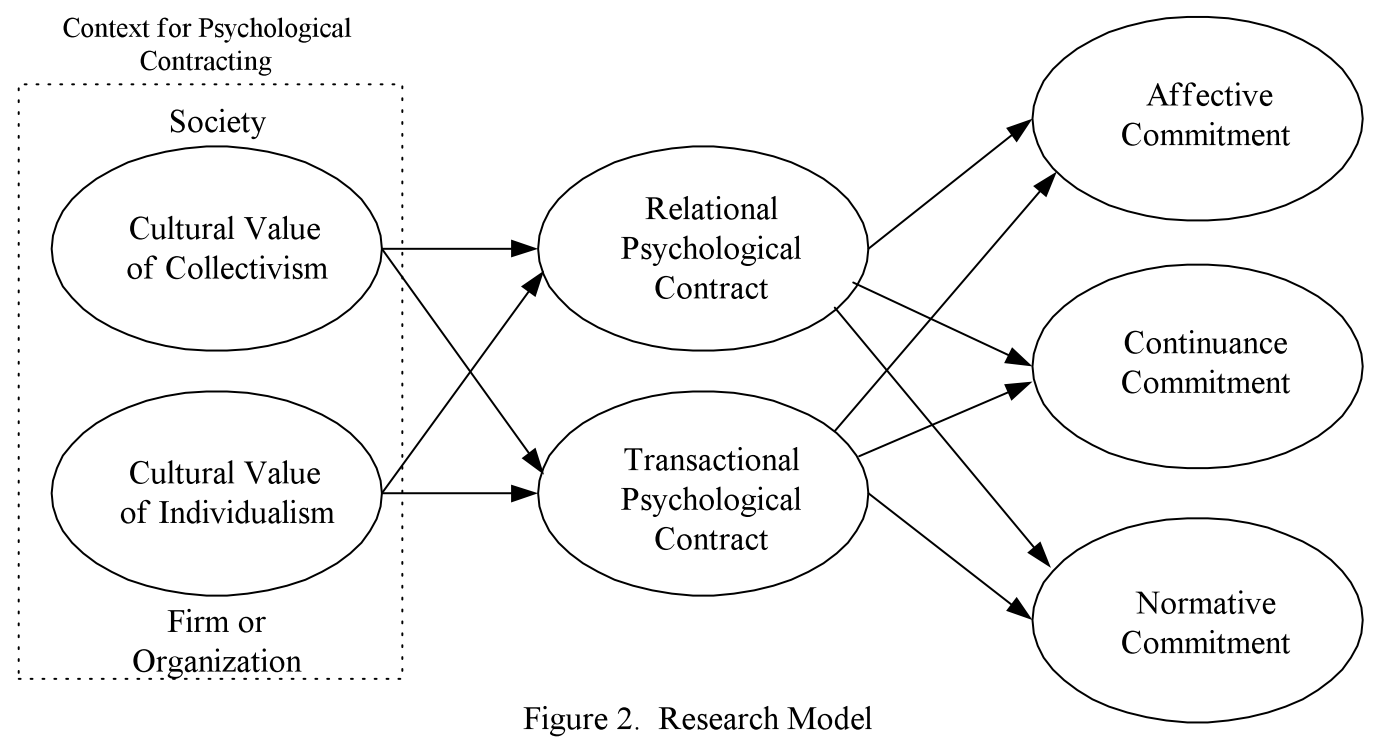

The psychological contract acts as a mediator in the model in Figure 2 and may take one of two forms (Rousseau, 1990) when constructed by the employee. A transactional psychological contract (Rousseau, 1990) involves the perceptions and expectations of money or other compensation from the employer to the employee, over a finite period of time, for completion of specific obligations and work by the employee (Robinson et al., 1994; Morishima, 1996). Market-competitive wages or salary and no commitment of long-term employment from the organization or by the employee are typical of the transactional contract (Robinson et al., 1994).

A relational psychological contract (Rousseau, 1990) also involves the perceptions and expectations of money or other compensation from the employer to the employee (Robinson et al., 1994; Morishima, 1996). However, other exchanges such as training, career development, and long-term employment with the company may also be perceived as important parts of the contract (Robinson et al. 1994). The time frame of the relational psychological contract is of indefinite duration and the obligations of the employee are often unclear and undefined (Morishima, 1996).

In the research model, the cultural values of individualism and collectivism serve as an antecedent to the psychological contract. Individualism and collectivism are framed as the context in which the employee has a predisposition toward the promises of the employer and the context in which the employee forms his or her internal interpretation of the elements presented by the organization. Within the context framework are the firm (or organization) and the society that affect, influence, and support the culture's values toward individualism or collectivism. 


\section{Geographic Distribution of the I/C Constructs}

The possibilities for research on the influence of individualism and collectivism (I/C) are considerable when considering the numerous countries, and their respective culture, that represent these cultural values. Certainly the United States, Great Britain, France, Germany, Finland, and Australia have long been considered as individualist cultures. China/Hong Kong, Japan, India, Brazil, and Mexico are clearly collectivist cultures. Great Britain and the United States versus China/Hong Kong and Japan represent two distinct pairs (Smith et al., 1989) of economically developed countries fertile for research in productivity and competitive advantage.

Japan set against the United States, taking into consideration the fiercely competitive relationship of the two economies over the past twenty-five years, is considered here as the exemplary comparative relationship for further investigation of the effects of individualism and collectivism (Triandis, 1995; Segall et al., 1999). Japan is a manufacturing economy which is as advanced as the U.S., thus the level of resource and capability development is comparable, and respective approaches to organizing are similarly effective (Hayes, 1981). Japan is a highly homogenous society with strong cultural traditions and distinctive institutions (Lincoln et al., 1986). The performance of Japanese manufacturing firms is classified among the best in the world. This makes it very hard to dismiss evidence of Japanese distinctiveness (Lincoln et al., 1986). Compared with the U.S., Japanese firms have taller organizational hierarchies, less functional specialization, less formal delegation of authority yet more participation in decisions at lower levels in the management structure. These structures are consistent with human resource practices of lifetime employment and seniority-based promotion that characterize many Japanese companies with the general emphasis of groups over individuals as the fundamental units of organization (Lincoln et al., 1986).

Cultural differences between Japanese and U.S. managers have been studied in the context of intercultural business negotiations (buyer-seller transactions) with findings that support the individualism/collectivism view of self-interest (Brett \& Okumura, 1998). Aspects of this view include the following points. In individualist cultures, (i) the definition of 'self' is independent from in-group membership; in collectivist cultures, self is interdependent with in-group membership (Triandis et al., 1990; Marcus \& Kitayama, 1991; Triandis, 1995). In individualist cultures, (ii) goals are independent of those of the in-group; in collectivist cultures, goals are aligned with those of the in-group (Triandis, 1995). In individualist cultures, (iii) there is an emphasis on personal needs; in collectivist cultures, the emphasis is on social/organizational and group obligations (Triandis, 1995).

\section{Organizational Aspects of Japanese Firms Supporting Collectivism}

In the Japanese business environment long-term cycles of exchange between individuals and organizations that promote extensive relationships are characteristic (Rousseau and Schalk, 2000). Japanese firms depend on continuous negotiations between employees and employer and thus form a strongly relational psychological 
contract (Morishima, 1996, 2000). Inter-dependence between employer and employee exists as the employer relies on the employee's skills and decision making abilities and the employee relies on the employer's ability to provide a stable job which gives value to his or her on-the-job skills (Morishima, 2000).

Employment relationships are expected to be long-term with an unspecified duration and employees are assumed to commit themselves (Ouchi, 1981; Morishima, 1996, 2000; Aoki, 1994). Long-term employment practices have promoted learning on the job that allows Japanese firms to develop organizational technologies that use employee inputs and involvement (Morishima, 2000). This Japanese human resource practice consists of implicit long-term employment guarantees for the regular core workforce (Hayes, 1981; Morishima, 1992). Additionally, Japanese employer policies and practices have been characterized as "welfare corporatism" (Morishima, 1992). Operationally, traditional Japanese human resource management practices, or welfare corporatism, of large firms may take three forms: (1) concern for employee welfare (Ouchi, 1981) or paternalism, (2) employment stabilization for regular workers (Cole, 1979; Koike, 1988) or long-term employment, and (3) emphasis on employee skill development (Cole, 1979; Koike, 1994). Japanese traditional human resource policies appear to be instrumental not only in obtaining worker commitment but also in maintaining cooperation and flexibility for management-initiated organizational change (Morishima, 1992).

Japanese management style is distinguished mainly by the sensitivity and concern with which Japanese managers treat their employees (Lincoln et al., 1981), also described as paternalism. Paternalism is consistent with a collectivist culture in which supervision would be considerate of the employee's needs with a much higher level of interaction with the employee and a reduced appreciation for the privacy and personal space of the employee (Smith et al., 1989). This is in contrast to the individualist culture where the supervisor would respect the employee's independence (Smith et al., 1989).

Additionally, a common observation of Japanese work organization structures is that organization charts rarely specify individual employee's positions and roles; they are rather, networks of collective units such as departments, sections, and work teams (Lincoln et al.,1986) which promote in-group identity. In sharp contrast to the relative lack of occupational or functional differentiation in Japanese organizations is the high degree of vertical status differentiation in the organizational structure (Lincoln et al., 1986). Like the pattern of dividing tasks among small groups rather than individuals, the tall hierarchies of Japanese firms are viewed as a structural reflection of permanent (long-term) employment and the seniority promotion system (Lincoln et al., 1986). The elaborate hierarchies mean there are opportunities for regular advancement over a lifetime career with the same firm and could be viewed as an expression of deep-seated cultural values (Lincoln et al., 1986). Lincoln et al. (1981) viewed vertical differentiation and relations as the foundation for the Japanese collectivity orientation in contrast to the U.S. orientation to occupational roles. 
Japanese organizations seek wide participation in each decision, and final action is postponed until consensus can be reached. This is different from the U.S. pattern in which individuals, rather than groups, are delegated responsibility for decisions and are subsequently held accountable for consequences (Smith, 1984; Lincoln et al., 1986; Misumi, 1990). In general, there is wide agreement that Japanese decision-making is group and consensus-oriented and involves low delegation of formal authority to positions held by individuals (Smith, 1984; Lincoln et al., 1986; Misumi, 1990). This style of decision-making aligns with the cultural value of collectivism.

Another human resource practice that adds to the framework of the relational psychological contract between Japanese employee and employer during the initial stages of employment is the composition of the personal assessment (personnel appraisal or merit rating in the United States). Future implications of the factors involved in the personal assessment inspire the worker's eagerness to perform his or her job, his or her work attitude as a group or team member, and his or her potential ability to perform jobs more effectively (Endo, 1994).

This system leads to the expectation of the employee of increased regular working hours, numerous overtime hours, and quasi-working hours (activities outside of working hours) as the employee forms the psychological contract of what is obligated to the employer. This obligation is promoted and implicitly communicated by the employer in a belief by Japanese managers that it fosters productivity improvements. The factors involved in the personal assessment also increase workers' obedience to management, since workers are under pressure to avoid at all costs any kind of behavior that might result in a poor assessment (Endo, 1994). The consequences of the personal assessment system lead to the behaviors of the Japanese employee to conform to the in-group that is consistent with the cultural value of collectivism.

\section{Organizational Aspects of United States Firms Supporting Individualism}

From the perspective of employment relationships and the formation of psychological contracts in the United States, three cultural characteristics are key contributors (Rousseau and Schalk, 2000). These cultural characteristics are: diversity of the population and subsequently the workforce, associability, which is distinguished by flexible relationships to multiple communities, and individualism (Rousseau \& Schalk, 2000). First, the United States is a highly pluralistic society in which numerous distinct ethnic, religious, and cultural groups coexist within one nation (Blau, 2000). In the United States, pluralism defines self as a person establishes his or her identity as he or she participates in multiple fragmented groups and worlds (Blau, 2000). No group, community, organization, or occupation claims one's undivided loyalty (Blau, 2000).

Subsequently, through the efforts of equal employment opportunity efforts to reduce discrimination, pluralism pervades throughout the business community and organizational structures creating diversity among the workforce. The workforce of the United States is becoming increasingly more diverse, thus strengthening individualism. As predicted by the turn-of-the-century, approximately 85 percent of the net additions to 
the workforce were women and non-white men, consisting primarily of Asian, African, and Hispanic Americans and immigrants (Cox et al., 1991).

At another level, the associability of individuals to society in the U.S. is bound by communalism (Triandis, 1995). Communalism is a theory or system of government in which communities are virtually autonomous and loosely bound in a federation (Webster's II, 2001). Further, the cultural value of individualism is inherent in the U.S. due to the country's founding on the concept that one should have freedom in one's economic pursuits and should succeed by one's own initiatives. Individualism by nature fosters respect among people for their achievements rather than their status (Rousseau \& Schalk, 2000). Individualism fosters attempts to actively master one's environment rather than passively accepting. In total, individualism is opposite to collectivism which typically means the subordination of individual freedom to focus on group identity and relationships (Rousseau and Schalk, 2000). Subsequently, an individualistic view which embraces change and refusal to accept things as they have been done before is characteristic of workers in the United States, while stability and long-term endurance characterize the collectivist view of workers in Japan (Rousseau and Schalk, 2000). In the U.S. there is a strong desire for individual freedom and equality, in few other societies is as much attention and effort expended on the individual (Hsu, 1983).

As stated earlier, the psychological contract of the Japanese (representing the collectivist culture) is primarily relational. Rousseau (1990) proposes that there are two types of contracts, transactional and relational, underlying agreements within and outside an organization. The psychological contract of the employee in the United States (representing the individualist culture) is primarily transactional. Transactional contracts involve specific tangible exchanges (such as salary, benefits) between the employee and employer (Rousseau, 1990). Highly competitive wage rates and the absence of long-term commitments are characteristic of transactional contracts (Rousseau, 1990; Robinson et al., 1994). Relational contracts, as characterized in the Japanese organization, are open-ended agreements established to maintain a relationship involving the exchange of both tangible and intangible rewards (such as hard work, loyalty, security) between the employee and the employer (Rousseau, 1990).

Firms with a strong value-oriented culture, common to Japan, typically foster relational contracts by making substantial commitments to their employees in the form of longterm employment in exchange for loyalty (Morishima, 1996). Strong value-oriented corporate cultures are characteristic of firms that have stable employment, low turnover, and promotion from within (Rousseau, 1990). Firms with a strong employee-employer exchange relationship oriented culture, common to the United States, typically foster transactional contracts based on the exchange of hard work by the employee for tangible rewards by the organization. Both transactional and relational psychological contracts have high levels of obligation (Shore \& Barksdale, 1998). An employee with a transactional contract would feel obligated to work hard if the individual perceived he or she was paid fairly. Conversely, an employee with a relational contract would feel obligated to stay with his or her employer if, for example, extensive investment had been made by the employer in the employee's development (Rousseau, 1995). 
As proposed, if the psychological contract of the employee in the United States is primarily transactional, it should be expected to remain that way through the foreseeable future. Careers and organizations in the United States have few boundaries. Career development will be more cyclical, involving periodic cycles of learning new skills (Mirvis \& Hall, 1994) for career changes. The career with few boundaries will be marked by lateral rather than upward mobility (Mirvis \& Hall, 1994). Workers will have to change jobs, companies and occupations over the span of their career. Subsequently, the primary responsibility for career development will shift more to the individual because organizations absent of career boundaries will not be able to plan an employee's career (Mirvis \& Hall, 1994).

\section{Propositions of the Study}

Specific hypotheses following from the theoretical background and proposed research model are as follows:

Hypothesis 1a: The higher the individual's level of collectivism the higher the individual's level of a relational type psychological contract.

Hypothesis 1b: The higher the individual's level of individualism the higher the individual's level of a transactional type psychological contract.

Hypothesis 2a: The higher the individual's level of a relational type psychological contract the higher the level of affective and normative commitment to the organization and the lower the level of continuance commitment.

Hypothesis 2b: The higher the individual's level of a transactional type psychological contract the higher the level of continuance commitment to the organization and the lower the level of affective and normative commitment.

Expectations of the research are that results of analysis will fully support the hypotheses. Specifically, there will be a statistically significant and positive relationship between collectivism and the relational psychological contract supporting Hypothesis 1a. There will be a statistically significant and positive relationship between individualism and the transactional psychological contract supporting Hypothesis $1 \mathrm{~b}$. Further, there will be a statistically significant and positive relationship between the relational psychological contract and affective and normative commitment supporting Hypothesis 2a. Finally, there will be a statistically significant and positive relationship between the transactional psychological contract and continuance commitment supporting Hypothesis $2 \mathrm{~b}$.

\section{Sampling Frame}

Suitable respondents for the study are mid-level managers and mid-career salaried professionals of Japanese-American firms located in the United States, Japanese firms located in Japan with subsidiaries in the United States, and American owned firms located in the United States that operate as direct competitors in the same industry as the Japanese-American firms. Potential cross-national sets of firms with the target 
sampling frame are in the automotive industry, battery manufacturing industry, electrical components/controls industry, and power tool industry. Participants in the study are expected to be native Japanese, Japanese-Americans, and Americans with no Japanese ancestry.

The organizational level and position of each participant are to be identified by each company based on the description of the target respondent provided to the firm by the researcher. White-collar employees who have not reached the upper levels of management within the company are considered to be the ideal respondent. This type of employee is expected to be marketable and have options in his or her employment decisions. The employee should not have reached a top management level in which extraordinary compensation arrangements exist that could alter his or her freedom of choice to leave the organization.

\section{Limitations}

It is proposed that firms operating in Japan and the United States be used in the study. In particular, Japanese-owned firms operating in the United States, whose work forces include native Japanese, Japanese-Americans, and Americans with no Japanese ancestry, are targeted as one of the appropriate settings for the test. The key disadvantage in studying Japanese-owned firms in the United States is that they are unusual organizations and may present findings that have little generality to other organizations.

The implications of cultural diversity in the United States may be profound. Cultural diversity in the United States may moderate the influence of individualism on the formation of the psychological contract. The U.S. is a melting pot of ethnic groups and people of different ethnic backgrounds possessing different attitudes, values, and norms that reflect their cultural heritage (Cox et al., 1991). Previous research has indicated that individualism-collectivism is an important dimension of cultural difference in nations in which the various ethnic groups of the United States have historical roots (Cox et al., 1991). Asian, African, and Hispanic Americans have roots in cultures with collectivist values (Triandis, 1995) and some carryover of the traditions of these cultures is found in these major ethnic groups in the U.S. (Cox et al., 1991); particularly in the form of group orientation and sense of community (Cox et al., 1991).

However, in support of future study, research has suggested that members of the predominant minority groups of the United States will tend to migrate to 'biculturalism' by adopting the norms of the majority-culture as well as their own ethnic group (Cox et al., 1991). Thus, it is postulated, that because of biculturalism major ethnic groups in the U.S. will respond to organizational situations based on the majority-culture orientation rather than minority-culture orientation (Cox et al., 1991). Contrary to this postulate are the results of the study conducted by Cox et al. (1991) which finds empirical evidence that ethnic group differences may continue to influence some aspects of behavior, particularly at the individual level where a more collectivist orientation was demonstrated (Cox et al., 1991). 
Another factor that may complicate the matter is that global organizations sometimes act as carriers (Aoki, 1994) of a set of behavioral rules originating at home, while they sometimes learn and adapt to market environments and institutional frameworks abroad (Aoki, 1994).

The above factors may alter the effect of cultural values on the formation of the psychological contract. Further exploration of the bases of trust, performance, and fulfillment is needed in psychological contracts where the parties are from different cultures (Rousseau \& Schalk, 2000), particularly in multi-national firms where different compositions of psychological contracts may be formed within the same organization.

\section{Implications for Research}

There is a new world economy that is characterized by interdependent work activities on both the national and global settings. Traditional concepts about work and time, such as long-term employment and job security, are in disorder and chaos (Arthur \& Rousseau, 1996). Changes in employment practices in Japan, in the form of evaluation on performance versus commitment and specified limited-term contracts versus long-term employment, have emerged in the late 1990s and early 2000s. The psychological contract between the employer and employee in the United States has also changed with the expectation of 'reasonably permanent employment for work well done'. Employees no longer regard their jobs as safe due to the extent of change in society and work over the past 20 to 25 years (Parks \& Kidder, 1994; Cooper, 1999). The impact of these changes on employee perception of the psychological contract, and consequently employee commitment, has not been examined empirically (Morishima, 2000).

\section{Implications for Practice}

Contemporary employment, particularly in firms that compete globally, has implied terms of employment signaling that workers will be required to adapt to new methods and techniques as needed. As global competition increases, it is foreseeable that strategic initiatives and organizational issues at the level of the firm will offer more powerful and clear explanations of psychological contracts with the workforce than either societal institutions (Rousseau \& Schalk, 2000) or cultural beliefs and values. As noted earlier, in the field of strategic management, and closely related operations management, significant interest exists in identifying and studying the historical competitive advantage of the Japanese manufacturing base over the U.S. The focus of studies has been predominantly centered on technology (machinery), management methods, and business policy. However, this study suggests that an aspect of manpower, organizational commitment of the workforce, may be a key factor.

The need for restructuring of the Japanese labor market has become apparent in the late 1990's and early 2000s due to doubts about the strengths and prospects of the Japanese economic system (Osawa \& Kingston, 1996). The stability and security of the 
lifetime employment system is now seen in some circles as a hindrance to overdue restructuring. Companies are backing away from career commitments that were, until recently, implicit. Jobs, promotion and pay will depend more on performance than under the current system. Job-hopping and mobility will increase and firms will be less reluctant to shed unproductive workers. The reciprocity of prevailing labor relations in Japan is giving way to a system where firms and employees will rely less on each other and look more to their own interests (Misumi, 1990; Osawa \& Kingston, 1996); an environment not too distinct from that of the United States over the past twenty years (Misumi, 1990; Fingleton, 1995).

\section{References}

Aoki, M. (1994). The Japanese firm as a system of attributes: A survey and research agenda. In M. Aoki and R. Dore (Eds.), The Japanese firm: Sources of competitive strength (pp. 11-40). New York: Oxford University Press.

Arai, K. (1998). Values, co-operation and lifetime employment. International Journal of Social Sciences, 25, 399-409.

Arthur, M. B., \& Rousseau, D. M. (1996). The boundaryless career: A new employment principle for a new organizational era. New York: Oxford University Press.

Barney, J. (1991). Firm resources and sustained competitive advantage. Journal of Management, 17, 99-120.

Blau, J. (2000). Spatial capital. In C. Leana \& D.M. Rousseau (Eds.), Relational wealth. New York: Oxford University Press.

Brett, J. M., \& Okumura, T. (1998). Inter- and intracultural negotiation: U.S. and Japanese negotiators. Academy of Management Journal, 41, 495-510.

Chase, R. B., Aquilano, N. J., Jacobs, F. R. (2001). Operations Management for Competitive Advantage. New York, NY: McGraw-Hill//rwin.

Cole, R. E. (1979). Work, Mobility, and Participation: A comparative study of American and Japanese Industry. Berkeley, CA: University of California Press.

Cooper, C. L. (1999). Hard decade at the office. Director, 53, p. 34.

Cox, T. H., Lobel, S., \& McLeod, P. (1991). Effects of ethnic group cultural differences on cooperative versus competitive behavior in a group task. Academy of Management Journal, 34, 827-847.

Dess, G. G., Lumpkin, G. T., Eisner, A. B. (2008). Strategic Management. New York, NY: McGraw-Hill Irwin. 
Endo, K. (1994). Satei (personal assessment) and interworker competition in Japanese firms. Industrial Relations, 33, 70-82.

Fingleton, E. (1995). Blind-side: Why Japan is Still Set to Overtake the U.S. by the Year 2000 (pp. 204-229). New York, NY: Simon Schuster.

Gakovic, A., \& Tetrick, L. E. (2003). Psychological contract breach as a source of strain for employees. Journal of Business and Psychology, 18, 235-246.

Hall, E. T. (1976). Beyond culture. Garden City, NY: Doubleday.

Hayes, R. H. (1981). Why Japanese factories work. Harvard Business Review, JulyAugust 1981, 57-66.

Hitt, M. A., Ireland, R. D., Hoskisson, R. E. (2007). Strategic Management: Competitiveness and Globalization. Mason, Ohio: Thompson South-Western.

Herscovitch, L., \& Meyer, J. P. (2002). Commitment to organizational change: Extension of a three-component model. Journal of Applied Psychology, 87, 474-487.

Hofstede, G. (1980). Culture's consequences: International differences in work-related values. Beverly Hills, CA: Sage.

Hsu, F. L. K. (1983). Rugged Individualism Reconsidered. Knoxville, TN: The University of Tennessee Press.

Koike, K. (1988). Understanding Industrial Relations in Modern Japan (pp. 51-73). London: Macmillan Publishing.

Koike, K. (1994). Learning and incentive systems in Japanese industry. In M. Aoki and R. Dore (Eds.), The Japanese firm: Sources of competitive strength (pp. 41-65). New York: Oxford University Press.

Lado, A. A., \& Wilson, M. C. (1994). Human resource systems and sustained competitive advantage: A competency-based perspective. Academy of Management Review, 19, 699-720.

Leana, C., \& Rousseau, D. M. (2000). Relational wealth. NY: Oxford University Press.

Lincoln, J. R., Hanada, M., \& McBride, K. (1986). Organizational structure in Japanese and U.S. manufacturing. Administrative Science Quarterly, 31, 338-364.

Lincoln, J. R., Hanada, M., \& Olson, J. (1981). Cultural orientations and individual reactions to organizations: A study of employees of Japanese-owned firms. Administrative Science Quarterly, 26, 93-116. 
Markus, H. R., \& Kitayama, S. (1991). Culture and self: Implications for cognition, emotion, and motivation. Psychological Review, 98, 224-253.

Meyer, J. P., \& Allen, N. J. (1991). A three-component conceptualization of organizational commitment. Human Resource Management Review, 1, 61-98.

Meyer, J. P., Allen, N. J., \& Smith, C. A. (1993). Commitment to organizations and occupations: Extension and test of a three-component conceptualization. Journal of Applied Psychology, 78, 538-551.

Mirvis, P. H., \& Hall, D. T. (1994). Psychological success and the boundaryless career. Journal of Organizational Behavior, 15, 365-380.

Misumi, J. (1990). The Japanese meaning of work and small group activities in Japanese industrial organizations. International Journal of Psychology, 25, 819-832.

Morishima, M. (1992). Japanese employees' attitudes toward changes in traditional employment practices. Industrial Relations, 31, 433-454.

Morishima, M. (1996). Renegotiating psychological contracts: Japanese style. In C. L. Cooper \& D. M. Rousseau (Eds.), Trends in organizational behavior (Vol. 3, pp. 139158). New York: John Wiley.

Morishima, M. (2000). A break with tradition: Negotiating new psychological contracts in Japan. In D. M. Rousseau \& R. Schalk (Eds.), Psychological contracts in employment: Cross-national perspectives (pp. 141-157). Thousand Oaks,CA: Sage.

Osawa, M., \& Kingston, J. (1996, January 1). Flexibility and inspiration: Restructuring and the Japanese labor market. Japan Labor Bulletin, pp.4-8.

Ouchi, W. G. (1981). Theory Z (pp.71-87). Reading, MA:Addison-Wesley.

Parks, J. M., \& Kidder, D. L. (1994). "Till death do us part....": Changing work relationships in the 1990s. In C.L. Cooper \& D. M. Rousseau (Eds.), Trends in organizational behavior (Vol. 1, pp. 111-136). New York: John Wiley.

Robinson, S. L., Kraatz, M. S., \& Rousseau, D. M. (1994). Changing obligations and the psychological contract: A longitudinal study. Academy of Management Journal, 37, 137152.

Rohleder, T. R., \& Silver, E. A. (1997). A tutorial on business process improvement. Journal of Operations Management, 15, 139-154.

Rousseau, D. M. (1989). Psychological and implied contracts in organizations. Employee Rights and Responsibilities, 2, 121-139. 
Rousseau, D. M. (1990). New hire perceptions of their own and their employer's obligations: A study of psychological contracts. Journal of Organizational Behavior, $11,389-400$.

Rousseau, D. M. (1995). Psychological contracts in organizations: Understanding written and unwritten agreements. Thousand Oaks, CA: Sage.

Rousseau, D. M. (2001). Schema, promise, mutuality: The building blocks of the psychological contract. Journal of Occupational and Organizational Psychology, 74, 511-541.

Rousseau, D. M., \& Schalk, R. (2000). Psychological contracts in employment: Crossnational perspectives. Thousand Oaks, CA: Sage.

Rousseau, D. M., \& Wade-Benzoni, K. A. (1994). Linking strategy and human resource practices: How employee and customer contracts are created. Human Resource Management, 33, 463-489.

Segall, M. H., Dasen, P. R., Berry, J. W., Poortinga, Y. H. (1999). Human behavior in global perspective; An introduction to cross-cultural psychology. Needham Heights, MA: Allyn \& Bacon/Pearson Education Company.

Shore, L. M., \& Barksdale, K. (1998). Examining degree of balance and level of obligation in the employment relationship: A social exchange approach. Journal of Organizational Behavior, 19, 731-744.

Shore, L. M., \& Tetrick, L. E. (1994). The psychological contract as an explanatory framework in the employment relationship. In C.L. Cooper \& D. M. Rousseau (Eds.), Trends in organizational behavior (Vol. 1, pp. 91-110). New York: John Wiley.

Smith, P. B. (1984). The effectiveness of Japanese styles of management: A review and critique. Journal of Occupational Psychology, 57, 121-136.

Smith, P. B., Misumi, J., Tayeb, M., Peterson, M., Bond, M. (1989). On the generality of leadership style measures across cultures. Journal of Occupational Psychology, 62, 97-109.

Thomas, D. C., \& Au, K. (2000). Cultural variation in the psychological contract. Academy of Management Proceedings, 2000 IM:F1.

Triandis, H. C. (1995). Individualism and Collectivism. Boulder, CO: Westview Press.

Triandis, H. C., McCusker, C., Hui, C. H. (1990). Multimethod probes of individualism and collectivism. Journal of Personality and Social Psychology, 59, 1006-1020.

Webster's II new college dictionary (2001). Boston: Houghton Mifflin Company. 